\title{
THE SHRINKING EARNINGS PREMIUM FOR UNIVERSITY GRADUATES IN HONG KONG: THE EFFECT OF QUANTITY OR QUALITY?
}

\author{
HON-KWONG LUI and WING SUEN*
}

Revised August 2004

\begin{abstract}
In 1989 the Hong Kong government embarked on a program to increase the provision of first-year first-degree places. The expansion of tertiary education represents a large and exogenous increase in supply of university graduates to the territory. This paper measures the labor market effects of the expansion program by studying the changes in earnings premium for university graduates. Two alternative hypotheses-crowding and quality effects-are identified to explain why the earnings premium shrank. The results support the view that the declining quality of university graduates is the prime candidate for the declining earnings premium.
\end{abstract}

JEL Code: J31, I28, J18

Correspondence to:

Hon-Kwong Lui

Department of Marketing \& International Business

Lingnan University

Tuen Mun

Hong Kong, CHINA

Voice: (852) 2616-8233

Fax: (852) 2467-3049

Email: hklui@ln.edu.hk 


\section{INTRODUCTION}

In 1989 the Hong Kong government embarked on a program that would increase the provision of first-year first-degree places from about 7 percent of the relevant age cohort to 18 percent. In the 1988-89 academic year, there were 19,496 undergraduates enrolled in government funded first-degree programs. Enrolment jumped to 47,467 in 1999-2000. This massive expansion of higher education represents an arguably exogenous increase in supply of university graduates. The proportion of degree holders in the workforce rose sharply from 7.4 percent in 1991 to 16.8 percent in 2001 (Census \& Statistics Department, 2002). However, a systematic evaluation of the effects of higher education expansion has not been performed to date. The present paper attempts to fill this gap.

Changes in wage structure have drawn the attention of economists for many years. Coleman (1993) documents the changes in the university premium in the United States from the 1940 s to the 1980 s. She finds that the earnings premium declined across the board during the 1940s and 1970s, and that it rose during the 1950s, 1960s, and 1980s. Although there was a large overall increase in supply of university graduates during the past few decades, the education premium for university graduates did not show any downward trend in the U.S. The leading hypothesis for the observed rise in college premium is skill-biased technical change. Once adjustment is made for a linear time trend in the demand for skilled labor, Katz and Murphy (1992) argue that changes in earnings premium in 1963 to 1987 can largely be explained by the changes in relative supply of university graduates (see also Goldin and Margo, 1992 and Burbidge et al., 2002). However, Taber (2001) argues that the returns to college education did not rise in the eighties but there was a substantial rise in variance of wage residuals. He attributes the observed rise in college premium to an increase in demand for unobserved skills (see also Chay and Lee, 2000).

The rapid expansion of higher education in Hong Kong offers a unique opportunity for us to tease out the effects of changes in demand and supply. If the underlying demand for college workers remains stable, observed changes in the college premium following the rise in supply due to the expansion program will provide an estimate of the demand elasticity for 
college workers. Arguably, however, the government's decision to expand university education is not exogenous. The government may have adopted its policy because it anticipated an increase in demand for skilled workers. In that case, the observed changes in the college premium will give a lower bound to the estimate of the demand elasticity for college workers. In any case, since the policy-induced change in supply of university graduates is expected to be larger and swifter than other changes in demand and supply due to demographics and technology during the same period, studying the experience of Hong Kong is useful for predicting the general equilibrium effects of an increase in supply of college graduates.

A recent paper by Duflo (2001) and a working paper by Clark and Hsieh (2000) also study the effects of major government policies to increase the supply of educated workers in Indonesia and Taiwan, respectively. Both studies focus on the use of government policies as instruments to measure the returns to education. The present study is similar to these two papers in that they exploit exogenous government policy to provide the means of identifying supply shifts. However, since there is no geographic variation in the implementation of the policy of expanding higher education in Hong Kong, the authors cannot use this policy as an instrumental variable for estimating the returns to education. Instead, the authors focus on measuring the general equilibrium effects of an economy-wide expansion in supply of college workers. Another difference between the present work and the earlier papers is that this paper deals with expansion in university education, while the earlier papers are about expansion in primary and lower secondary education. To the extent that universal education at the primary and lower secondary level has been achieved in many countries in east and southeast Asia, the sector that is poised for further expansion is tertiary education. The results of this study are therefore particularly relevant for the formulation of education policies in Hong Kong and the region.

Another contribution of this paper is that the authors go beyond measuring the labor market effects of the expansion of higher education to investigate the reasons behind the observed changes. The authors distinguish between two hypotheses: crowding out and 
deteriorating quality. While both hypotheses suggest that an expansion of higher education tend to reduce the university earnings premium, they have different predictions regarding the earnings premium for older cohorts and for university graduates who were educated overseas. A proper understanding of the role of these two channels is important, as it may suggest ways to design policies that mitigate the adverse impact of a large increase in supply on the wages of educated workers.

\section{Background}

The oldest tertiary institution in Hong Kong, the University of Hong Kong, was founded in 1911. Until the 1960s the number of university places was very limited and admissions to university were effectively confined to students from upper income families. In 1963 the Chinese University of Hong Kong was established by expanding and amalgamating three existing colleges. University enrolment experienced a steady increase during the 1960 s and 1970s.

In Hong Kong all universities are heavily subsidized by the government through the University Grants Committee (UGC) of Hong Kong. In 1989 higher education system entered a new era of rapid expansion as the government decided to increase the numbers of first-year first-degree places substantially. In the 1989-90 academic year, less than nine percent of the 17-20 age cohort (i.e., about 7,400 school leavers) were admitted to firstdegree courses (French, 1997). At that time, the government set a target that, by 1994-95, 18 percent of the 17-20 age cohort would have access to first-year first-degree places. In other words, the number of first-degree places would be doubled in five years. This target was achieved in three ways: (1) by expanding existing university places; (2) by establishing a new university (viz., the Hong Kong University of Science and Technology); and (3) by converting polytechnics and colleges into universities that offer recognized first-degree programs. Figure 1 shows that total student enrolment in UGC-funded programs more than doubled between 1989 and 1995, and stabilized afterward. Enrolment was increasing since 
1984 but the rate of increase accelerated in since 1989. By 1995, the government's target was largely met.

\section{(Insert Figure 1 Here)}

Hong Kong now has seven universities, an open university, as well as three other degree-awarding institutions. The expansion of tertiary education in Hong Kong is reflected in the increase in amount of approved grants to UGC-funded institutions, for which a longer time series is available. The data are shown in Figure 2. In 1990-91, the Hong Kong government allocated $\mathrm{HK} \$ 3,496$ million $(\mathrm{US} \$ 1=\mathrm{HK} \$ 7.8)$ in recurrent grant to UGCfunded institutions. In a decade, the approved recurrent grant increased more than three-fold to HK\$ 12,311 million (source: UGC Secretariat). A structural break in the time series of recurrent funding can be detected in the late 1980s. Figure 2 also shows that the amount of capital grant rose permanently to a higher level after the academic year 1990-91. ${ }^{1}$

(Insert Figure 2 Here)

The large increase in funding that occurred during the expansionary stage means that spending per university student has not declined. Indeed the UGC has introduced various measures to monitor the work of universities. These measures include management review, Research Assessment Exercise, and Teaching and Learning Quality Process Review. Moreover, Teaching Development Grants and Language Enhancement Grants totaling more than HK\$ 312 million were allocated by the UGC to enhance teaching and learning at tertiary level (French, 1997). Following the tradition of the British system, external advisors, external assessors or external examiners are involved in virtually all aspects of higher education in Hong Kong. While these measures may ensure that the value-added in the education process does not deteriorate, they cannot address that the problem that the quality of student intake may fall as more university places become available.

\section{METHODOLOGY}

The expansion of higher education results in an increase in supply of university graduates in the workforce. From 1981 to 2001, the proportion of degree holders in the Hong Kong 
workforce increased drastically from 5.3 percent to 16.8 percent (Census \& Statistics Department, 1988; 2002). This paper measures the effect of this increase in supply by examining changes in the earnings premium for university graduates relative to those with upper secondary education. Before one can argue that the expansion of higher education has caused a change in relative wage structure, the issue of simultaneity bias must be addressed.

Presumably, changes in government policies are not entirely random. One reason why the Hong Kong government decided to massively increase the availability of first-degree places was to accommodate an expected increase in the demand for skilled labor. This research will examine the changes in demand for skilled labor by looking at the wage structure for workers with different years of work experience (Juhn, 1999; Bartel and Sicherman, 1999). If the demand for skilled labor has really risen, relative earnings for degree holders would have risen in the absence of an increase in supply of degree holders. Therefore, measured change in the earnings premium for university graduates will provide a lower bound estimate of the effect of increased supply on relative wages.

There are at least two reasons why expanding higher education may shrink the earnings premium for university graduates. First, if university graduates and other workers or other factors of production are imperfect substitutes, increasing the supply of university graduates will result in diminishing returns. This is a factor proportions or crowding effect (Bergsman, 1982; Dolado et al., 2000). Related to the crowding effect is a downgrading of the type of jobs that require a university degree. As the supply of university graduates becomes more plentiful, they begin to take jobs that previously do not require a university degree. If the wage rate attached to any particular job does not change, this will explain why the ratio of average wage of university graduates falls relative to that of secondary school graduates. In terms of neoclassical theory, one can think of this change in job requirements as the result of having more high skilled labor with the same amount of capital (productive jobs). A predictable outcome is diminishing wages (marginal product) for these high skilled workers. 
Second, as universities take in more and more students, the quality of the student intake may fall. Moreover, the quality of higher education may also be affected if existing university resources cannot effectively cope with the increased student intake. Lower student quality will be reflected in lower productivity and therefore lower wages (Bedi and Edwards, 2002). To distinguish between these two hypotheses, the authors propose to use a "difference in differences approach" (see, for example, Angrist and Krueger, 1999).

Implicit in the authors' approach is the assumption that the competitive model accurately describes labor markets in Hong Kong. If the expansion of tertiary education led to adjustments in terms of employment level rather than wages, then measured wages need not accurately reflect the demand-supply balance. The authors note that before the Asian financial crisis, the unemployment rate in Hong Kong remained at a very low level for many years. From 1989 to 1997 , the unemployment rate was not more than $3.2 \%$ and the economy can be described as at full employment level. In the fourth quarter of 2001 , the unemployment rates for the general labor force and for university graduates were 6.1 and $3.5 \%$, respectively (Census \& Statistics Department 2003). The expansion did not seem to have any significant adverse impact on the employment of university graduates.

One may also argue that the expansion program could affect the emigration pattern, which would subsequently affect the earnings premium. Emigration in Hong Kong was largely pushed by political factors (Asia Pacific Migration Research Network, 1997). From a peak of around 60,000 per annum in 1990-1994, emigration dropped to the 40,000 level for 1995-1997 and further fell to the 10,000 level for 1998-2003 (Government Information Centre, 2004). Apparently the expansion of tertiary education embarked in 1989 did not significantly increase emigration from Hong Kong. In particular, there is no evidence that young university graduates who faced diminished employment opportunities had responded by leaving Hong Kong. Similarly, Skeldon (1995) shows that the expatriate community (which is primarily made up of skilled professional workers) in Hong Kong was growing in size and complexity even after the expansion program. There is no indication that the expansion of higher education in Hong Kong has any noticeable impact on immigration 
pattern of foreign professionals that might have upset the demand-supply balance of local workers.

\section{A. The Difference in Differences Approach}

It should noted that the crowding effect will affect all degree holders, whereas the quality effect only affects people who obtained their degrees in Hong Kong since the expansion program began. For a university degree holder who graduated in 1980, say, his relative earnings will fall to the extent that new graduates crowd the market and reduce the scarcity value of degree holders, but his relative earnings will not fall simply because the more recent graduates are of lower quality. Therefore, a "difference in differences" approach can be adopted to test the two alternative hypotheses. If the relative earnings of more recent graduates (who enter university after the expansion program was in effect) fall more sharply than the relative earnings of early graduates, one can conclude that the quality effect is mainly responsible for the shrinking university earnings premium. Otherwise, the crowding effect is the more likely candidate explanation.

Suppose the mean log earnings of recent university graduates, early university graduates, recent upper secondary graduates, and early upper secondary graduates in period $t$ $(t=1,2)$ are $\bar{X}_{t}^{R U}, \bar{X}_{t}^{E U}, \bar{X}_{t}^{R S}$, and $\bar{X}_{t}^{E S}$, respectively. If the reduction in earnings premium is due to the crowding effect, we should observe that:

$$
\left(\bar{X}_{1}^{E U}-\bar{X}_{1}^{E S}\right)-\left(\bar{X}_{2}^{E U}-\bar{X}_{2}^{E S}\right)=\left(\bar{X}_{1}^{R U}-\bar{X}_{1}^{R S}\right)-\left(\bar{X}_{2}^{R U}-\bar{X}_{2}^{R S}\right) .
$$

On the other hand, if declining quality of university graduates is the prime candidate for the declining earnings premium, we should observe that:

$$
\left(\bar{X}_{1}^{E U}-\bar{X}_{1}^{E S}\right)-\left(\bar{X}_{2}^{E U}-\bar{X}_{2}^{E S}\right)<\left(\bar{X}_{1}^{R U}-\bar{X}_{1}^{R S}\right)-\left(\bar{X}_{2}^{R U}-\bar{X}_{2}^{R S}\right) .
$$

The "difference in differences" approach can also be applied to local university graduates versus graduates from overseas universities. The expansion of higher education in Hong Kong should have little impact on the quality of university education elsewhere. Therefore, if the relative earnings of degree holders who recently graduated from universities 
in Hong Kong fall more sharply than do the relative earnings of degree holders who recently graduated from universities overseas, one can conclude that the quality effect is in operation. If, on the other hand, the changes in earnings premium for both groups are of similar magnitude, the crowding effect will be the better explanation for the shrinking premium.

\section{B. Data Sets}

This paper makes use of individual level data from the random sub-samples of the 1981 (5\%), 1986 (14\%), 1991 (5\%), 1996 (5\%), and 2001 (5\%) Hong Kong population censuses. In Hong Kong the normal age for completing a first-degree is 22. By looking at the changes in earnings premium of young graduates in comparison to other control groups, we can understand whether and why the expansion of higher education shrinks the earnings premium. In each data set, the authors only select full-time workers who were aged 21 to 40 and were born in greater China (i.e., Hong Kong, Chinese Mainland, Macau, and Taiwan). Then, the authors divide each random sample into four different age groups, namely, 21-25, 26-30, 31-35, and 36-40. Within each age group, the authors further divide it into male and female workers to control for gender differences.

As discussed in the previous section, the authors are also interested in the changes in earnings premium of local versus overseas educated university graduates. Thus, within each age group, the authors also divide the college workers into those who received their education overseas and those who received their education locally. This information is not available from the 1981 population census. So, the discussion will be based on the sub-samples of the 1986, 1991, 1996, and 2001 population censuses.

Although the population censuses contain detailed demographic and socio-economic variables of the respondents, these data sets are only available every five years. In order to analyze the changes in earnings premium for university graduates between two census years, the authors have to look for supplementary data sets. In Hong Kong, the statistical authority conducts a quarterly General Household Survey (GHS), which aims to collect basic information on the labor force, employment, unemployment and underemployment. In any 
quarter, around 24,000 households are interviewed. The authors extract relevant information from the GHS quarterly files and analyzed the data using the difference in differences approach. Although GHS data are much noisier than random sub-samples of population censuses and they do not contain information about where a worker obtained his or her degree, they can be used to ensure that the trends established through an analysis of census years are indeed long term trends rather than temporary fluctuations.

\section{EMPIRICAL RESULTS}

\section{A. University Graduates vs. Upper Secondary Graduates}

Table 1 presents the earnings premium for graduates by sex and by educational level. From Table 1A, we can see that the overall earnings premium for male graduates aged $21-40$ increased drastically from 0.73 in 1981 to 0.85 in 1986 . The earnings premium declined steadily thereafter to 0.67 in 2001 , almost back to its initial level in 1981 . The earnings premium for female university graduates followed a similar pattern. It rose from 0.73 to 0.88 between 1981 and 1986. By 2001, the premium fell back to 0.65. Although the timing of the decline in the college premium is suggestive of a relation with the expansion of higher education during the late 1980 s, such evidence is not sufficient to allow us to draw any firm conclusions. $^{2}$

\section{(Insert Table 1 Here)}

The picture becomes much clearer if we break down the analysis by age groups. Panels B, C, D, and E of Table 1 show the university earnings premium for workers in the $21-25,26-30,31-35$, and $36-40$ age groups. Table $1 \mathrm{~B}$ shows that the earnings premium for male university graduates relative to male upper secondary graduates shrank mildly from 1981 to 1991 . Following the British higher education system, a typical first degree program in Hong Kong lasts for 3 years and a typical fresh university graduate is around 22 years of age. With the expansion of tertiary education in 1989, the supply of graduate aged 21 to 25 experienced a marked increase in 1992. The proportion of university graduates in this age cohort of the total workforce increased from $4.8 \%$ in 1991 to $13.7 \%$ in 1996 . The impact of 
this graduate boom was reflected in the earnings premium, which showed a marked decrease from 0.50 in 1991 to 0.40 in 1996.

In 2001, twelve years after the expansion program, tertiary institutions have had more time to consolidate their degree programs. The labor market also had more time to adjust to the supply shock. The earning premiums for male university graduates continued to decline from 0.40 in 1996 to 0.37 in 2001 . The earnings premium in 2001 was substantially lower than its level in the 1980s. This pattern applies equally to female university graduates in the same age group.

The difference in differences analysis results (with 1981 as the reference year) tabulated in the last two columns of Table 1B clearly indicate declining earnings premium for university graduates during the period from 1981 to 2001 . A negative value means a decline in earnings premium in a particular year when compared with that of 1981. The differences are statistically significant. This declining trend in earnings premium contrasts with the increasing student enrolment during the same period.

In Table 1C, we see that the earnings premium for people aged 26-30 also experienced a statistically significant and quantitatively substantial decline. More importantly, the decline for this group was the greatest in the year 2001 (falling from 0.62 in 1996 to 0.53 in 2001). If we use a birth cohort perspective, the 26-30 age group in 2001 is the same birth cohort as the 21-25 age group in 1996. We saw earlier in panel B that the decline in the university earnings premium was also the greatest for this birth cohort when they were 21 to 25 years old. This observation strongly suggests that the decline in earnings premium was caused by the expansion in higher education, which has the greatest impact on individuals who were aged 16-20 (the age suitable for college) in the year 1991.

From Figure 1, we can see that when the government expanded the enrolment of firstdegree programs, it also increased the enrolment of postgraduate programs. The earnings premium for postgraduate degree holders is higher than that for first-degree holders. If the proportion of higher degree holders in the labor market increased substantially, the observed earnings premium for graduates would be biased upward after the expansion program began. 
Figure 1 shows the increase in postgraduate programs was in a much smaller scale when compared with the expansion of undergraduate programs. Full-time taught masters programs last for one to two years, while part-time programs normally last for two to three years. Moreover, the duration of research degree programs vary considerably from two to five years. Hence the expansion of tertiary education embarked in 1989 should not noticeably increase the supply of workers with a higher degree.

If the falling university earnings premium is due to the crowding effect, the effect should equally affect university graduates in other age groups as well. However, panels D and $\mathrm{E}$ of Table 1 show that university graduates of older age groups actually experienced an increase in their earnings premium from 1981 to 2001. While almost all values in the last two columns of Tables $1 \mathrm{D}$ and $1 \mathrm{E}$ are positive, figures shown in Tables $1 \mathrm{~B}$ and $1 \mathrm{C}$ are predominantly negative in value. This piece of evidence supports the view that the declining quality of university graduates is the prime candidate for declining earnings premium.

Although census files contain rich information, snapshots taken at five-year intervals may not be representative of underlying trends. The authors make use of data collected in the General Household Surveys to fill this gap. In order not to overburden readers with numbers, the authors choose not to present detailed difference-in-differences analysis results based on the 1986 to 2000 GHS data sets. Instead, the authors plot change in the earnings premium relative to that in 1986 for university graduate (relative to upper secondary school graduates) for the $21-25$ and the 36-40 age groups. Figure 3 refers to male workers while Figure 4 corresponds to female workers.

(Insert Figure 3 and Figure 4 Here)

Figure 3 shows that the earnings premium for male university graduates aged 36-40 was rather stable. It bounced up and down within a narrow range. The pattern for university graduates aged $21-25$ is very different. The earnings premium for young male university graduates experienced a steady decline of about 0.20 throughout the 1990s. Figure 4 reveals that the underlying trend for female university graduates is broadly similar to that of their male counterparts. These two figures clearly indicate that the expansion of tertiary education 
in Hong Kong has reduced the earnings premium for younger university graduates but not for older graduates. This result is consistent with the hypothesis that the quality of university graduates who received their education since the expansion program begun has declined.

One may argue, however, changes in earnings premium could be affected by changes in the age-earnings profile across educational groups. As the authors already divide each random sample into four different age cohorts, changes in the age-earnings profile should be largely controlled for. Alternatively, in order to control for variations in socio-economic characteristics one could use a standard earnings regression to estimate the returns to schooling. The authors have also run several earnings regressions with sex, experience, experience squared, marital status, employment status and educational level. In addition, four dummy variables representing degree holders of four age cohorts are also included as independent variable. In 1981, the difference in coefficient estimates for degree holders aged $21-25$ and $31-35$ is -0.114 . The earnings gap widened to -0.308 in 2001 . The widening earnings gap shows that the earnings premium for younger university graduates was declining relative to older graduates. These results tell essentially the same story as the difference in differences analysis adopted in this paper.

\section{B. Local vs. Overseas Graduates}

Although the comparison between younger and older cohorts provides some evidence that declining quality is a more likely candidate explanation for the declining university earnings premium than is the crowding effect, such evidence is by no means conclusive. If younger university graduates and older university graduates are not perfect substitutes, then the recent expansion of higher education will have a greater negative effect on the college premium for younger workers than its effect on the college premium for older workers (Card and Lemieux, 2001). ${ }^{3} \quad$ The authors therefore further examine the issue by exploiting the difference between university graduates who obtained their degrees in Hong Kong and those who obtained the degrees from overseas. Even if younger workers and older workers are not perfect substitutes, the crowding effect predicts that the expansion of tertiary education in 
Hong Kong will have an equal negative impact on the earnings of all young university graduates, regardless of the place where they got their degrees. If the declining college premium is due to falling standards, on the other hand, it should be particularly manifest among locally-educated workers, since foreign universities are not significantly affected by the expansion program. Hence, we can use overseas educated university graduates as a reference group to compare with the earnings of locally trained graduates. Table 2 presents the earnings premium for local and overseas graduates

(Insert Table 2 Here)

The authors compute the earnings premium for local graduates by subtracting the mean log earnings of overseas graduates from the mean log earnings of local graduates. A positive value indicates that local graduates receive higher earnings than do overseas graduates. Since both groups are university graduates, crowding effects should apply equally to both groups. Therefore, the relative earnings of these two groups should remain unaffected by crowding. Panel A of Table 2, however, shows that for the whole sample of graduates aged 21 to 40, the earnings premium of local graduates recorded a marked decrease. In 1986 locally-educated university graduates earned 0.14 (for males) and 0.28 (for females) more than overseas graduates. By 2001 the earnings advantage of local graduates had almost completely vanished.

The authors have run $t$-tests on the earnings premium for local graduates relative to that of overseas graduates. The results for earlier years are significantly positive whereas the results for 2001 are insignificant. Since the authors are using 5\% random sub-sample of 2001 population census, the number of observations is large. (The data set has over 12,200 and 8,800 records of male and female university graduates, respectively.) The $t$-test results do not reject the null hypothesis that the earnings premium for local graduates is zero in 2001. In other words, the mean log incomes of local and overseas graduates are more or less the same. The results render strong support to the hypothesis that declining quality of local university education is the major cause of the declining earnings premium for college workers. 
Breaking down the results by age groups reveals an even more interesting pattern. For male university graduates aged $21-25$, the earnings premium for local graduates fell by 0.14 from 1986 to 2001 (see Table 2B). For the age group 36-40, local male graduates fell by only 0.05 during the same period (see Table $2 \mathrm{E}$ ). Indeed the earnings differences between local graduates and overseas graduates had become insignificant for the younger age groups, but they remain positive and significant for the older age groups. A similar pattern also holds for female graduates. The data therefore indicate that the earnings advantage for local graduates has shrunk by more for the younger age group than for the older age group, an observation which is consistent with the local expansion of higher education in recent years.

\section{Robustness Checks}

To make sure that the declining college premium and the pattern across age cohorts are not confined to the mean of the earnings distribution, the authors examine other quintiles of the distribution as well. For each age group, the authors divide the sample of university graduates into five quintile groups and compute the average earnings for each group. Similarly, for each age group, the authors compute the average earnings for the five earnings quintile groups among upper secondary school graduates. Table 3 presents the earnings premium of the lowest and highest quintile earnings groups for the 21-25 and 36-40 age groups. From panels A and B, the authors can see that the earnings premium for graduates of the youngest age cohorts experienced a marked decrease. The magnitude of decline in earnings premium is largely comparable between both income groups. On the other hand, the earnings premium for graduates of the oldest cohort recorded a noticeable increase at both the upper and lower end of the earnings distribution (panels $\mathrm{C}$ and $\mathrm{D}$ ). These patterns are very similar to those observed using the mean of the distribution.

Another robustness check that is needed is to ensure the results are not sensitive to the choice of the benchmark group. In this paper, the authors have used workers with upper secondary education as the comparison group for college graduates. The advantage of using this comparison group is that the sample size is large. Arguably, however, the earnings 
premium for university graduates can also be computed using as the comparison group workers who have matriculated (finished Form 6 or 7) or completed non-degree courses. Hence the authors repeat their analysis by replacing secondary school graduates by these two groups of workers. The results are broadly comparable with the previous analysis. During the period from 1981 to 2001 , the earnings premium for young graduates aged 21 to 15 narrowed by 0.125 when compared with these two groups of workers. For workers aged 36 to 40 , the earnings premium widened by 0.40 and 0.15 respectively.

\section{CONCLUDING REMARKS}

In 1989 the Hong Kong government embarked on a program to increase the provision of first-year first-degree places from 7 percent of the 17-20 age cohort to 18 percent. The number of university students doubled in five years. Since university places are tightly controlled by the government, the expansion program represents an exogenous increase in supply of university graduates to the labor market. This paper shows that the increase in supply has brought about a decline in the earnings premium for college workers. Moreover, the decline is more substantial among younger workers than among older workers. The authors also find that locally educated university graduates used to earn significantly more than did overseas graduates. Their earnings advantage, however, had declined between 1986 and 2001, particularly among the younger age group. These observations suggest that the decline in the university earnings premium is probably more the result of declining quality of university graduates than of a labor market crowding effect.

Sorting out the reasons for the declining college premium has implications for public policy. If the crowding effect is the major cause, this means the demand for college workers is rather inelastic, so that the labor market cannot accommodate a large increase in supply of college workers without reducing their wage. In that case, policy makers may have to rethink whether Hong Kong should continue its policy of expanding post-secondary education. If declining quality of university graduates is the major cause, then the policy focus should fall on how to improve the quality of higher education. In Section 2, the authors show that 
total spending on higher education had kept pace with the increase in number of university places. The authors believe that the decline in quality of university graduates is mostly due to a fall in the quality of the student intake rather than a reduction in the value-added of local universities. If this is true, then one policy to arrest the decline in student quality would be to let in more students from mainland China and from overseas. If universities do not have to tap lower and lower down the student ability distribution for their source of students, the authors expect that the quality - and hence the earnings - of the graduates could be maintained at a more stable level. 


\section{REFERENCES}

Angrist, J. D., and A. B. Krueger. "Empirical Strategies in Labor Economics." In O. Ashenfelter and D. Card, eds., Handbook of Labor Economics, 1999, Vol. 3A. Amsterdam: North-Holland, 1277-1366.

Asia Pacific Migration Research Network. Migration Issues in the Asia Pacific: Issues Paper from Hong Kong. APMRN Secretariat Centre for Multicultural Studies - Institute for Social Change \& Critical Inquiry ; University of Wollongong, Australia, 1997.

Bartel, A. P., and N. Sicherman. "Technological Change and Wages: An Interindustry Analysis." Journal of Political Economy 107 (April), 1999, 285-325.

Bedi, A. S., and J. H. Y. Edwards. "The Impact of School Quality on Earnings and Educational Returns-Evidence from a Low-income Country." Journal of Development Economics 68 (June), 2002, 157-185.

Bergsman, J. “Apartheid, Wages, and Production Costs in South Africa: An Application of the Crowding Hypothesis.” Journal of Human Resources 17 (Fall), 1982, 633-645.

Betts, J. R. "Does School Quality Matter? Evidence from the National Longitudinal Survey of Youth.” Review of Economics and Statistics 77 (May), 1995, 231-247.

Blackaby, D. H., K. Clark, D. G. Leslie and P. D. Murphy. "The Distribution of Male and Female Earnings 1973-91: Evidence for Britain." Oxford Economic Papers 49 (April), 1997, $256-272$.

Blau, F. D., and L. M. Kahn. "Swimming Upstream: Trends in the Gender Wage Differential in the 1980s." Journal of Labor Economics 15, Part 1 (January), 1997, 1-42.

_ _ and __. "Understanding International Differences in the Gender Pay Gap." Journal of Labor Economics 21 (January), 2003, 106-144.

Burbidge, J.B., L. Magee, and A. L. Robb. "The Education Premium in Canada and the United States." Canadian Public Policy 28 (June), 2002, 203-217.

Card, D., and A. B. Krueger (1992). "Does School Quality Matter? Returns to Education and the Characteristics of Public Schools in the United States" Journal of Political Economy 100 (February): 1-40. 
_ , and T. Lemieux. "Can Falling Supply Explain the Rising Return to College for Younger Men? A Cohort-Based Analysis." Quarterly Journal of Economics 116 (May), $2001,705-746$.

Census \& Statistics Department. Hong Kong 1986 By-Census: Main Report, Vol. 2. Hong Kong: Government Printer, 1988.

_ . 2001 Population Census: Main Report, Vol. 1. Hong Kong: Printing Department, 2002.

_. Quarterly Report on General Household Survey: October to December 2002. Hong Kong: Printing Department, 2003.

Chay, K. Y., and D. S. Lee. "Changes in Relative Wages in the 1980s: Returns to Observed and Unobserved Skills and Black-White Wage Differentials." Journal of Econometrics 99 (November), 2000, 1-38.

Clark, D. E., and C.-T. Hsieh. "Schooling the Labor Market Impact of the 1968 Nine-Year Education Program in Taiwan.” Working paper, University of California, Berkeley, 2000.

Coleman, Mary T. "Movements in the Earnings-Schooling Relationship, 1940-88." Journal of Human Resources 28 (Summer), 1993, 660-680.

Dearden, L., J. Ferri and C. Meghir. "The Effect of School Quality on Educational Attainment and Wages." Review of Economics and Statistics 84, (February), 2002, 1-20.

Dolado, J. J., F. Felgueroso and J. F. Jimeno. "Youth Labour Markets in Spain: Education, Training, and Crowding-Out.” European Economic Review 44 (May), 2000, 943-956.

Dolton, P., D. O. Neill, and O. Sweetman. "Gender Differences in the Changing Labor Market: The Role of Legislation and Inequality in Changing the Wage Gap for Qualified Workers in the United Kingdom.” Journal of Human Resources 31 (Summer), 1996, 549565.

Duflo, E. "Schooling and Labor Market Consequences of School Construction in Indonesia: Evidence from an Unusual Policy Experiment." American Economic Review 91 (September), 2001, 795-813. 
French, N. J. "Higher Education in Hong Kong: Recent Developments and Future Challenges." Paper Presented at the World Congress on Higher Education in the AsiaPacific Region, Manila, Philippines, 1997.

Government Information Centre. Emigration. (http://www.info.gov.hk/info/emigrat.pdf), 2004.

Goldin, C., and R. A. Margo. "The Great Depression: The Wage Structure in the United States at Mid-Century." Quarterly Journal of Economics 107 (February), 1992, 1-34.

Heckman, J. J., A. S. Layne-Farrar, and P. E. Todd. "Human Capital Pricing Equations with an Application to Estimating the Effect of School Quality on Earnings." Review of Economics and Statistics 78 (4), 1996, 562-610.

Hunt, J. "The Transition in East Germany: When is a Ten-point Fall in the Gender Wage Gap Bad News?” Journal of Labor Economics 20 (January). 2002, 148-169.

Johnson, G. E., and F. P. Stafford. "Social Returns to Quantity and Quality of Schooling." Journal of Human Resources 8 (Spring), 1973, 139-155.

Juhn, C. "Wage Inequality and Demand for Skill: Evidence from Five Decades." Industrial \& Labor Relations Review 52 (April), 1999, 424-443.

Katz, L. F., and K. M. Murphy. "Changes in Relative Wages, 1963-1987: Supply and Demand Factors.” Quarterly Journal of Economics 107 (February), 1992, 35-78.

Loeb, S., and J. Bound. "The Effect of Measured School Inputs on Academic Achievement: Evidence from the 1920s, 1930s, and 1940s Birth Cohorts." Review of Economics and Statistics 78 (4), 1996, 653-664.

Moffitt, R. A. "Symposium on School Quality and Educational Out-comes: Introduction." Review of Economics and Statistics 78 (4), 1996, 559-561.

Rosholm, M., and N. Smith. “The Danish Gender Wage Gap in the 1980s: A Panel Data Study." Oxford Economic Papers 48 (April), 1996, 254-279.

Skeldon, R. "Immigration and Population Issue." In S.Y.L. Cheung and S.M.H. Sze eds, The Other Hong Kong Report 1995, The Chinese University Press, Hong Kong, 303-316, 1995. 
Suen, W. "Estimating the Effects of Immigration in One City." Journal of Population Economics 13 (January), 2000, 99-112.

Taber, C. R. "The Rising College Premium in the Eighties: Return to College or Return to Unobserved Ability?" The Review of Economic Studies 68 (July), 2001, 665-691. 


\section{FOOTNOTES}

*We thank Andrew Gill and two anonymous referees for useful comments and suggestions that significantly improved the quality of the paper. We are also grateful to the Secretariat of University Grants Committee of Hong Kong for providing statistics on tertiary education in Hong Kong.

Lui: Associate Professor, Department of Marketing \& International Business, Lingnan University, Tuen Mun, Hong Kong. Phone: (852) 2616-8233, Fax: (852) 2467-3049, Email: hklui@ln.edu.hk.

Suen: Professor, School of Economics \& Finance, The University of Hong Kong, Pokfulam Road, Hong Kong. Phone: (852) 2859-1052, Fax: (852) 2548-1152, Email: hrneswc@hkusua.hku.hk.

1. The dramatic rise in capital grant in 1990-91 reflects funding for the establishment of the Hong Kong University of Science and Technology. This initial funding was gradually phased out after 1995-96, but the amount of capital grant remained at a level substantially higher than that before 1990 .

2. In particular, the observed decline in earnings premium for university graduates between 1986 and 2001 could simply reflect a temporary increase in the premium during 1986 instead of a secular downward trend.

3. Suen (2000) made a similar point in the context of estimating the effects of increased immigration. 


\section{ABBREVIATIONS}

UGC: University Grants Committee

GHS: General Household Survey 
FIGURE 1

Student Enrolment on UGC Funded Programs

$1984 / 1985$ to $1999 / 2000$

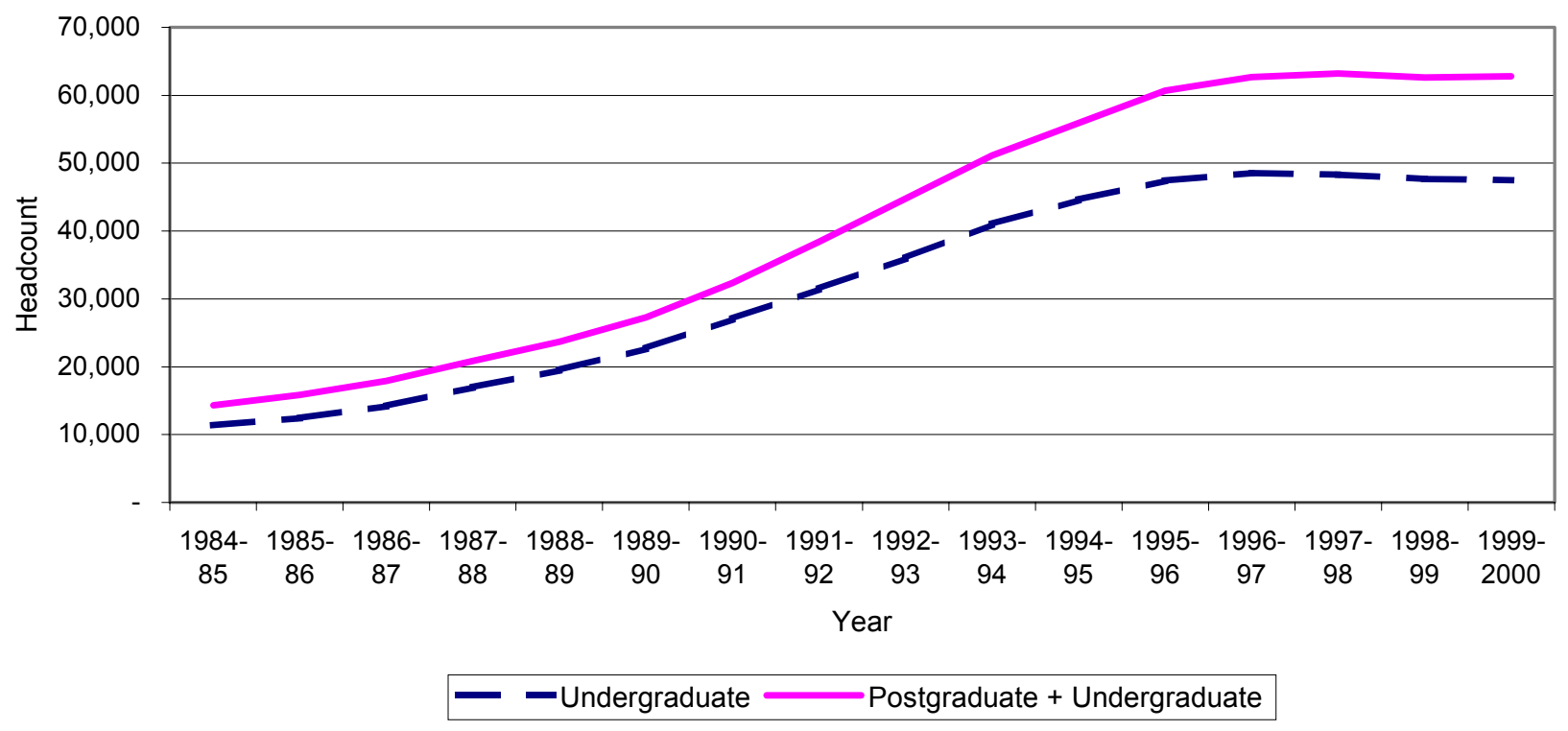

Source: UGC Secretariat 
FIGURE 2

Approved Grants to UGC Funded Institutions $1955 / 1956$ to $1999 / 2000$

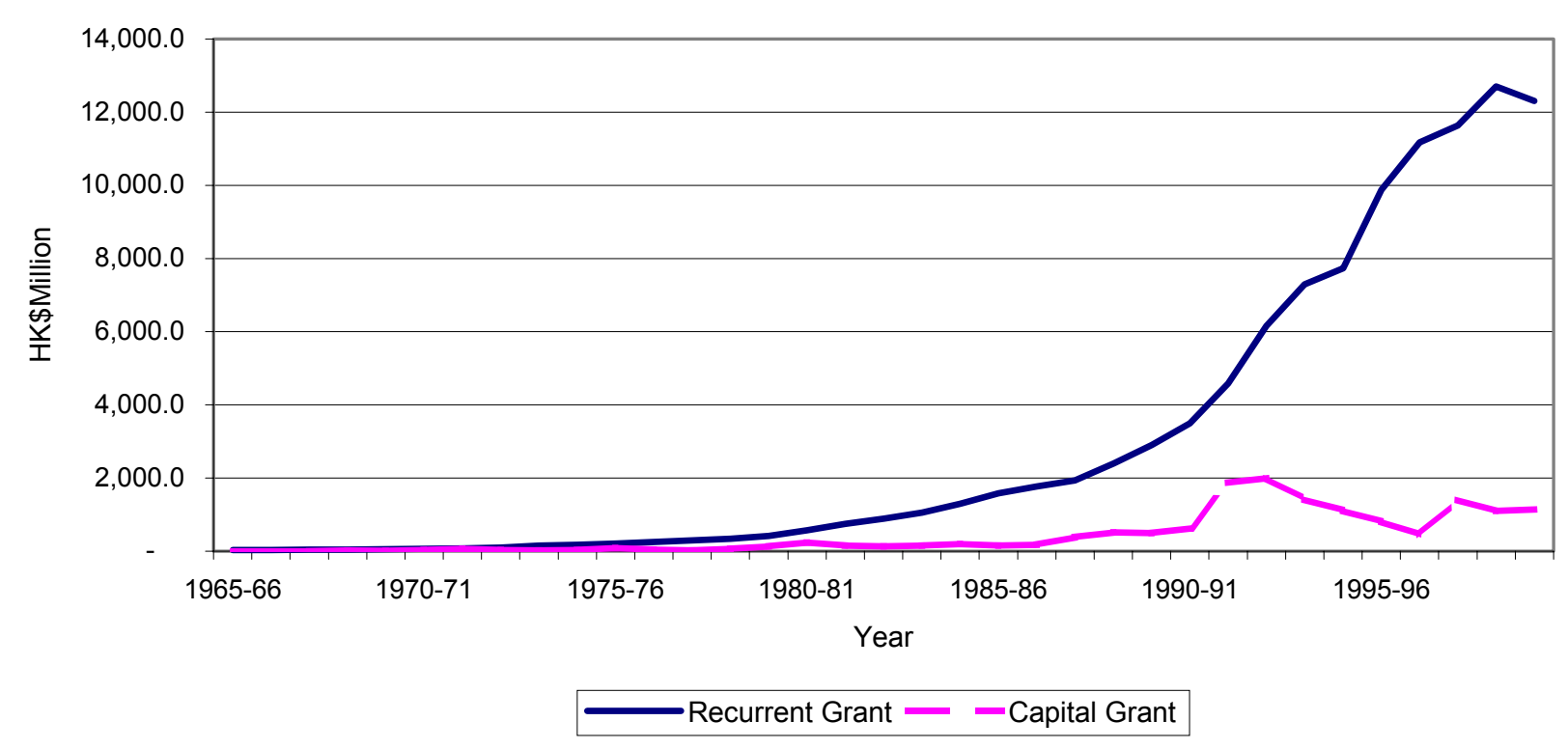

Source: UGC Secretariat 
FIGURE 3

Difference in Differences Analysis (Male Workers) 1986 to 2000

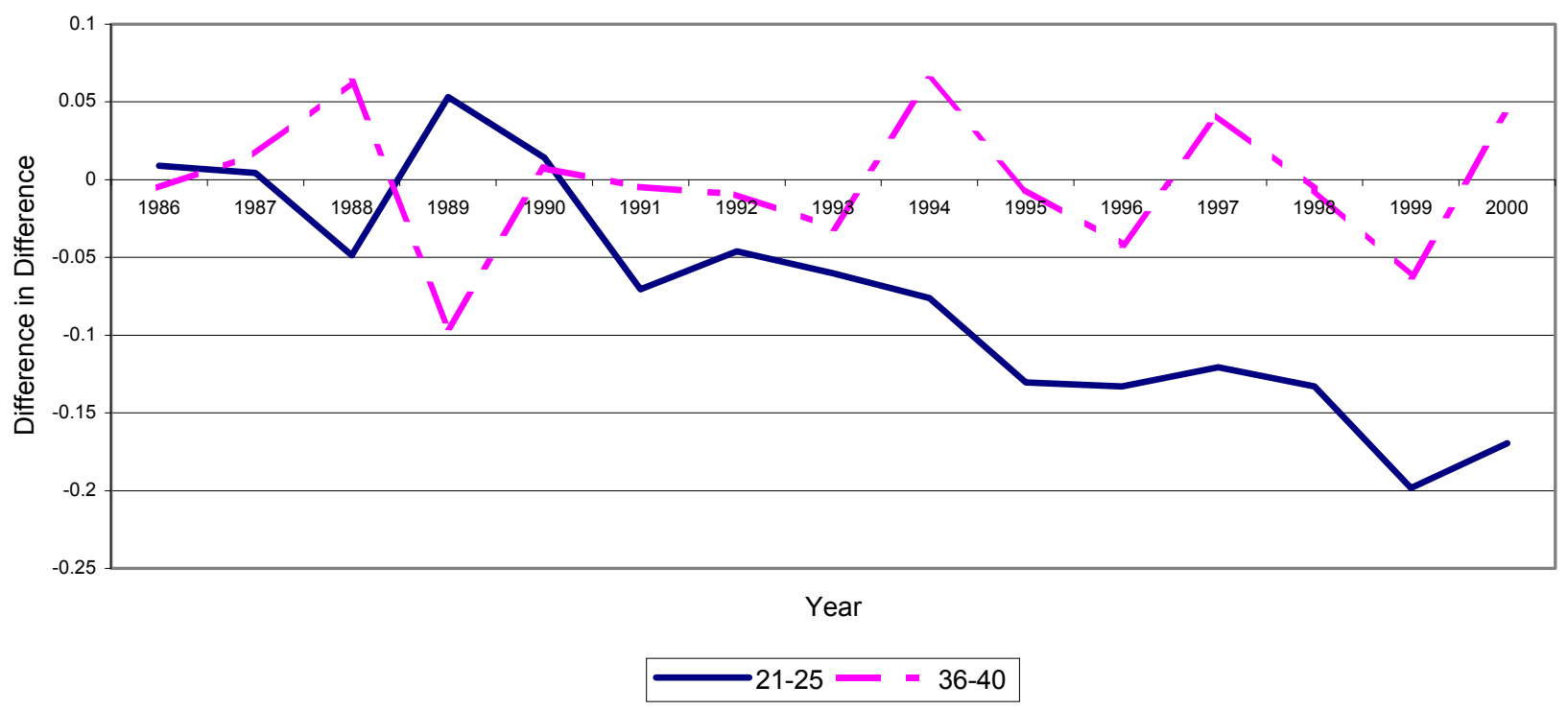


FIGURE 4

Difference in Differences Analysis (Female Workers) 1986 to 2000

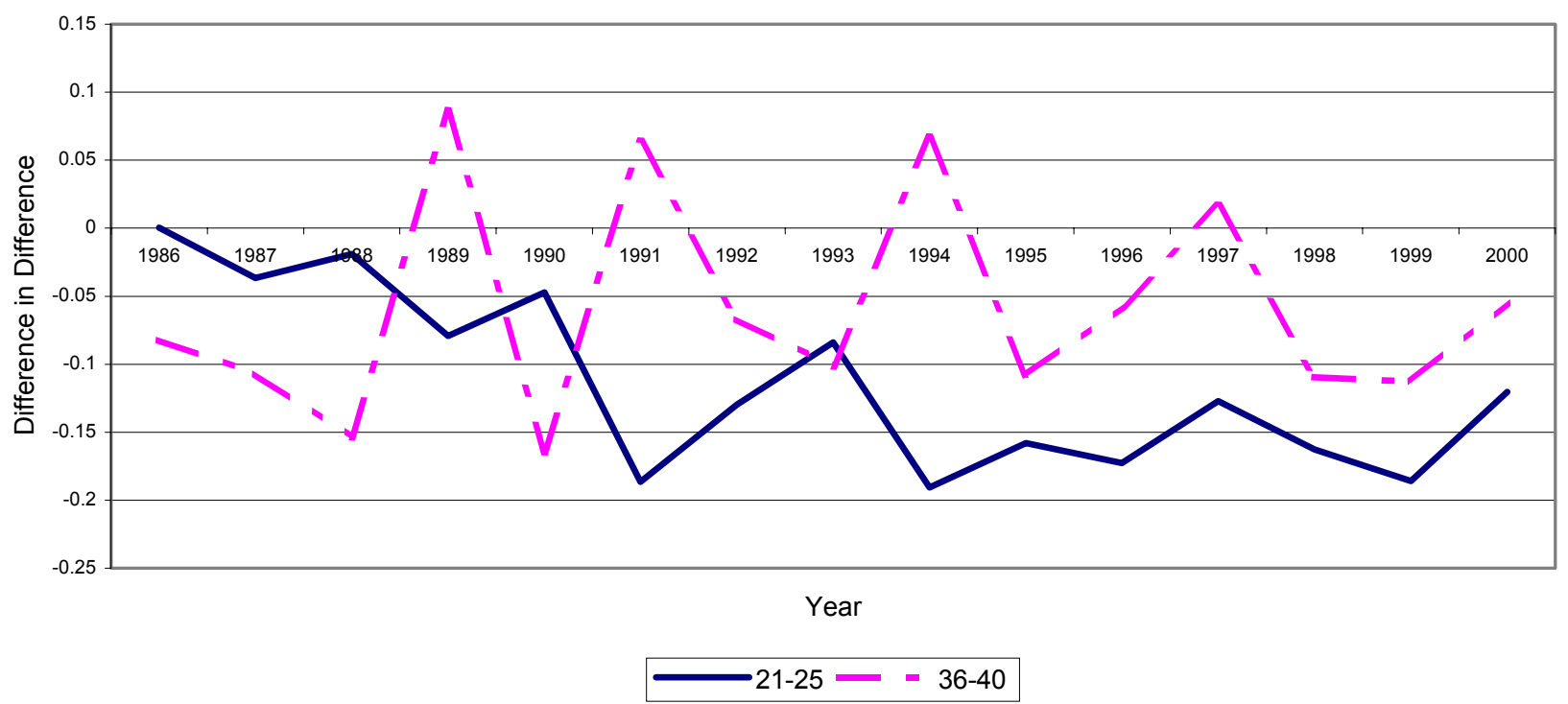


TABLE 1

Earnings Premium for Graduates

\begin{tabular}{|c|c|c|c|c|c|c|}
\hline \multirow{2}{*}{ Year } & \multicolumn{2}{|c|}{ Earnings Premium } & \multicolumn{2}{|c|}{ Diff in Diff (1981) } & \multicolumn{2}{|c|}{ s.e. (Diff in Diff) } \\
\hline & Male & Female & Male & Female & Male & Female \\
\hline \multicolumn{7}{|c|}{ (A) Aged 21 - 40 (Overall) } \\
\hline 1981 & $0.730423^{* * *}$ & $0.730133^{* * *}$ & \multicolumn{4}{|c|}{ N. A. } \\
\hline 1986 & $0.853131^{* * *}$ & $0.883112^{* * *}$ & 0.122708 & 0.152979 & 0.021566 & 0.031391 \\
\hline 1991 & $0.798401^{* * *}$ & $0.799389^{* * *}$ & 0.067978 & 0.069256 & 0.023433 & 0.033114 \\
\hline 1996 & $0.723198^{* * *}$ & $0.663878^{* * *}$ & -0.007225 & -0.066255 & 0.021568 & 0.030582 \\
\hline 2001 & $0.666424^{* * *}$ & $0.651758^{* * *}$ & -0.063999 & -0.078375 & 0.021064 & 0.030041 \\
\hline \multicolumn{7}{|c|}{ (B) Aged $21-25$} \\
\hline 1981 & $0.636650^{* * *}$ & $0.714383^{* * *}$ & \multicolumn{4}{|c|}{ N. A. } \\
\hline 1986 & $0.551969^{* * *}$ & $0.689724^{* * *}$ & -0.084581 & -0.024659 & 0.029869 & 0.040955 \\
\hline 1991 & $0.503451^{* * *}$ & $0.574839^{* * *}$ & -0.133099 & -0.139544 & 0.032904 & 0.044802 \\
\hline 1996 & $0.401284^{* * *}$ & $0.418450^{* * *}$ & -0.235266 & -0.295933 & 0.029152 & 0.039411 \\
\hline 2001 & $0.374701^{* * *}$ & $0.424370^{* * *}$ & -0.261849 & -0.290013 & 0.028760 & 0.039049 \\
\hline \multicolumn{7}{|c|}{ (C) Aged 26-30 } \\
\hline 1981 & $0.680295^{* * *}$ & $0.760994^{* * *}$ & \multicolumn{4}{|c|}{ N. A. } \\
\hline 1986 & $0.698228^{* * *}$ & $0.813682^{* * *}$ & 0.017933 & 0.052688 & 0.029112 & 0.041753 \\
\hline 1991 & $0.608576^{* * *}$ & $0.711261^{* * *}$ & -0.071719 & -0.049733 & 0.031795 & 0.044151 \\
\hline 1996 & $0.614616^{* * *}$ & $0.645809^{* * *}$ & -0.065679 & -0.115185 & 0.029989 & 0.041155 \\
\hline 2001 & $0.527292^{* * *}$ & $0.571761^{* * *}$ & -0.153003 & -0.189233 & 0.029406 & 0.040082 \\
\hline \multicolumn{7}{|c|}{ (D) Aged $31-35$} \\
\hline 1981 & $0.764986^{* * *}$ & $0.824797^{* * *}$ & \multicolumn{4}{|c|}{ N. A. } \\
\hline 1986 & $0.864100^{* * *}$ & $0.901533^{* * *}$ & 0.099114 & 0.076736 & 0.046183 & 0.080486 \\
\hline 1991 & $0.868468^{* * *}$ & $0.864478^{* * *}$ & 0.103482 & 0.039681 & 0.048882 & 0.083560 \\
\hline 1996 & $0.771737^{* * *}$ & $0.748766^{* * *}$ & 0.006751 & -0.076031 & 0.046005 & 0.079016 \\
\hline 2001 & $0.765660^{* * *}$ & $0.777986^{* * *}$ & 0.000674 & -0.046811 & 0.045821 & 0.077997 \\
\hline \multicolumn{7}{|c|}{ (E) Aged 36 - 40 } \\
\hline 1981 & $0.487588^{* * *}$ & $0.243400^{*}$ & \multicolumn{4}{|c|}{ N. A. } \\
\hline 1986 & $0.872537^{* * *}$ & $0.878232^{* * *}$ & 0.384949 & 0.614832 & 0.062275 & 0.109777 \\
\hline 1991 & $0.946061^{* * *}$ & $0.995654^{* * *}$ & 0.458473 & 0.732254 & 0.065138 & 0.111087 \\
\hline 1996 & $0.936591^{* * *}$ & $0.954045^{* * *}$ & 0.449003 & 0.690645 & 0.061031 & 0.103989 \\
\hline 2001 & $0.881311^{* * *}$ & $0.892868^{* * *}$ & 0.393723 & 0.649468 & 0.058892 & 0.101014 \\
\hline
\end{tabular}

Note: Earnings Premium $=\log$ income (Degree) - log income (Upper Sec)

$H_{0}$ : Earnings Premium $=0$

* Significant at 0.05 level

*** Significant at 0.001 level 
TABLE 2

Earnings Premium for Local vs. Overseas Graduates

\begin{tabular}{|c|c|c|c|c|c|c|}
\hline \multirow{2}{*}{ Year } & \multicolumn{2}{|c|}{ Earnings Premium } & \multicolumn{2}{|c|}{ Diff in Diff (1986) } & \multicolumn{2}{|c|}{ s.e. (Diff in Diff) } \\
\hline & Male & Female & Male & Female & Male & Female \\
\hline \multicolumn{7}{|c|}{ (A) Aged 21 - 40 (Overall) } \\
\hline 1986 & $0.144129^{* * *}$ & $0.283152^{* * *}$ & \multicolumn{4}{|c|}{ N. A. } \\
\hline 1991 & $0.069359^{* *}$ & $0.084489^{* *}$ & -0.074770 & -0.198663 & 0.030533 & 0.039453 \\
\hline 1996 & $-0.046923^{* * *}$ & 0.031693 & -0.191052 & -0.251459 & 0.024413 & 0.029968 \\
\hline 2001 & 0.011206 & 0.000675 & -0.132923 & -0.282477 & 0.023209 & 0.028230 \\
\hline \multicolumn{7}{|c|}{ (B) Aged $21-25$} \\
\hline 1986 & $0.187199^{* * *}$ & $0.217536^{* * *}$ & \multicolumn{4}{|c|}{ N. A. } \\
\hline 1991 & $0.134340^{* * *}$ & $0.147229^{* *}$ & -0.052859 & -0.070307 & 0.052229 & 0.063159 \\
\hline 1996 & -0.004245 & 0.020920 & -0.191444 & -0.196616 & 0.043131 & 0.045131 \\
\hline 2001 & 0.012260 & 0.014729 & -0.174939 & -0.202807 & 0.045534 & 0.046611 \\
\hline \multicolumn{7}{|c|}{ (C) Aged 26-30 } \\
\hline 1986 & $0.201142^{* * *}$ & $0.210259^{* * *}$ & \multicolumn{4}{|c|}{ N. A. } \\
\hline 1991 & $0.092225^{* *}$ & $0.091382^{*}$ & -0.108917 & -0.118877 & 0.041215 & 0.052586 \\
\hline 1996 & 0.030173 & $0.079066^{* *}$ & -0.170969 & -0.131193 & 0.034928 & 0.042186 \\
\hline 2001 & 0.048540 & 0.031555 & -0.152602 & -0.178704 & 0.034278 & 0.038476 \\
\hline \multicolumn{7}{|c|}{ (D) Aged $31-35$} \\
\hline 1986 & $0.166230^{* * *}$ & $0.380196^{* * *}$ & \multicolumn{4}{|c|}{ N. A. } \\
\hline 1991 & $0.215946^{* * *}$ & 0.109055 & 0.049716 & -0.271141 & 0.051633 & 0.080086 \\
\hline 1996 & 0.039215 & $0.157761^{* * *}$ & -0.127015 & -0.222435 & 0.041308 & 0.058868 \\
\hline 2001 & $0.103852^{* * *}$ & $0.118294^{* * *}$ & -0.062378 & -0.261902 & 0.040552 & 0.054793 \\
\hline \multicolumn{7}{|c|}{ (E) Aged 36-40 } \\
\hline 1986 & $0.240275^{* * *}$ & $0.516834^{* * *}$ & \multicolumn{4}{|c|}{ N. A. } \\
\hline 1991 & $0.125430^{* *}$ & $0.320857^{* * *}$ & -0.114845 & -0.195977 & 0.071010 & 0.120965 \\
\hline 1996 & 0.044446 & $0.180719^{* * *}$ & -0.195829 & -0.336115 & 0.055671 & 0.096802 \\
\hline 2001 & $0.187930^{* * *}$ & $0.180360^{* * *}$ & -0.052345 & -0.336474 & 0.048662 & 0.086135 \\
\hline
\end{tabular}

Note: Earnings Premium = log income (Local Graduate) - log income (Overseas Graduate)

$H_{0}:$ Earnings Premium $=0$

* Significant at 0.05 level

** Significant at 0.01 level

*** Significant at 0.005 level 
TABLE 3

Earnings Premium for Graduates by Quintile Income Group

\begin{tabular}{|c|c|c|c|c|c|c|}
\hline \multirow{2}{*}{ Year } & \multicolumn{2}{|c|}{ Earnings Premium } & \multicolumn{2}{|c|}{ Diff in Diff (1981) } & \multicolumn{2}{|c|}{ s.e. (Diff in Diff) } \\
\hline & Male & Female & Male & Female & Male & Female \\
\hline \multicolumn{7}{|c|}{ (A) 21 - 25: Lowest Quintile Income Group } \\
\hline 1981 & $0.577069^{* * *}$ & $0.501278^{* * *}$ & \multicolumn{4}{|c|}{ N. A. } \\
\hline 1986 & $0.485498^{* * *}$ & $0.497282^{* * *}$ & -0.091571 & -0.003996 & 0.040342 & 0.074037 \\
\hline 1991 & $0.503943^{* * *}$ & $0.372051^{* * *}$ & -0.073126 & -0.129227 & 0.042545 & 0.082155 \\
\hline 1996 & $0.394182^{* * *}$ & $0.340477^{* * *}$ & -0.182887 & -0.160801 & 0.040853 & 0.072124 \\
\hline 2001 & $0.370615^{* * *}$ & $0.384205^{* * *}$ & -0.206454 & -0.117073 & 0.040685 & 0.073572 \\
\hline \multicolumn{7}{|c|}{ (B) 21 - 25: Highest Quintile Income Group } \\
\hline 1981 & $0.625495^{* * *}$ & $0.731309^{* * *}$ & \multicolumn{4}{|c|}{ N. A. } \\
\hline 1986 & $0.649943^{* * *}$ & $0.808015^{* * *}$ & 0.024448 & 0.076706 & 0.038297 & 0.049873 \\
\hline 1991 & $0.499874^{* * *}$ & $0.664228^{* * *}$ & -0.125621 & -0.067081 & 0.045782 & 0.059348 \\
\hline 1996 & $0.416669^{* * *}$ & $0.482318^{* * *}$ & -0.208826 & -0.248991 & 0.042870 & 0.046566 \\
\hline 2001 & $0.433896^{* * *}$ & $0.546909^{* * *}$ & -0.191599 & -0.184400 & 0.040006 & 0.044053 \\
\hline \multicolumn{7}{|c|}{ (C) $36-40$ : Lowest Quintile Income Group } \\
\hline 1981 & $0.020408^{* * *}$ & $0.131970^{* * *}$ & \multicolumn{4}{|c|}{ N. A. } \\
\hline 1986 & $0.384758^{* * *}$ & $0.459027^{* * *}$ & 0.364350 & 0.327057 & 0.063872 & 0.104210 \\
\hline 1991 & $0.551804^{* * *}$ & $0.761474^{* * *}$ & 0.531396 & 0.629504 & 0.068097 & 0.106673 \\
\hline 1996 & $0.722472^{* * *}$ & $0.812277^{* * *}$ & 0.702064 & 0.680307 & 0.063217 & 0.099170 \\
\hline 2001 & $0.708674^{* * *}$ & $0.748603^{* * *}$ & 0.688266 & 0.616633 & 0.059335 & 0.093743 \\
\hline \multicolumn{7}{|c|}{ (D) 36 - 40: Highest Quintile Income Group } \\
\hline 1981 & $1.014478^{* * *}$ & $0.686008^{* * *}$ & \multicolumn{4}{|c|}{ N. A. } \\
\hline 1986 & $1.052716^{* * *}$ & $0.946171^{* * *}$ & 0.038238 & 0.260163 & 0.069047 & 0.093487 \\
\hline 1991 & $1.107720^{* * *}$ & $1.205735^{* * *}$ & 0.093242 & 0.519727 & 0.070932 & 0.095982 \\
\hline 1996 & $1.147980^{* * *}$ & $1.145774^{* * *}$ & 0.133502 & 0.459766 & 0.067880 & 0.092517 \\
\hline 2001 & $1.078098^{* * *}$ & $1.017409^{* * *}$ & 0.063620 & 0.331401 & 0.065085 & 0.087642 \\
\hline
\end{tabular}

Note: Earnings Premium $=\log$ income (Degree) - log income (Upper Sec)

$H_{0}:$ Earnings Premium $=0$

*** Significant at 0.001 level 